\title{
Are we there yet? Research with and for teachers and children and the possibilities of schooling in a complex world
}

\section{Annette Woods ${ }^{1}$ (D)}

Received: 18 December 2020 / Accepted: 28 January 2021 / Published online: 18 February 2021

(C) The Australian Association for Research in Education, Inc. 2021

\begin{abstract}
Shifting the relationship between schooling, social justice and equity, and the present and future experiences of children, young people, and their families and communities, has been a focus of educational research, and indeed policy and practice, for many decades. In this paper, I discuss education and its preparedness to work towards social justice, by drawing on examples across a number of studies. While I consider the possibilities for teachers and young people and children in schools today and present several counter narratives to those in popular circulation, I also detail initiatives that I engaged in with members during the time I was President of AARE. The point is to highlight social justice issues in education in Australia and highlight some ways forward.
\end{abstract}

Keywords Equity $\cdot$ Social justice $\cdot$ Schooling $\cdot$ Educational research

\section{Introduction}

Shifting the relationship between schooling, social justice and equity, and the present and future experiences of children, young people, and their families and communities, has been a focus of educational research, and indeed policy and practice, for many decades. Current conditions of schooling are embedded in the present social, cultural, economic, material and political contexts of now. These impact on the ways that systems and institutions can provide for the diverse range of children and young people attending schools. And there is little doubt that these conditions are continually changing and that the change is becoming more rapid. Certainly 2020 has demonstrated that many things we have taken for granted can change without notice. However, when I recently reread the formative work of Connell et al. on schools,

Annette Woods

annette.woods@qut.edu.au

1 Queensland University of Technology, Brisbane, Australia 
families and social division (Connell et al. 1982), I noted that these researchers argued that "central government policy now tends to increase educational inequality rather than reduce it" (p. 16). So almost four decades on, and while the policy, practices and conditions of schooling may be different, it seems that so much remains the same. Here, my point is primarily to discuss education and its preparedness to work towards equity and social justice. There is a particular focus on schools within communities that are currently left to deal with the impacts of national and international policy trends that serve the interests of a few, but at the expense of many. These same communities have been left to carry a disproportionate load of the 2020 COVID-19 crisis in education, social, health and economic terms.

In this paper, I have taken some liberties with the genre of the academic paper, deciding to write in a more narrative style than I might usually allow myself to do. This has been in part because I have found it difficult to justify 'cleaning up' the oral presentation given as the 2018 Presidential Address into a more traditional academic paper. However, I have also opted for this more narrative approach as a way to bring together the experience of being President of the Australian Association for Researchers in Education (AARE) with other elements of my research and academic work. The paper presents a discussion on poverty and its position within educational opportunity and social justice. Then drawing on examples across a number of studies I consider the possibilities for teachers and young people and children in schools today and present several counter narratives to those in popular circulation. Finally, I ask readers to consider the role of educators-researchers, teachers, and leaders-in finding ways to collaborate towards social justice education. Intertwined throughout the discussion are details of three critical initiatives for AARE which standout as important as I look back on my time as President - the Statement of Reconciliation; the Working Party on academic working conditions and the separation of teaching and research within the academy; and moves to build alliances with other Associations as a way to take up a more strategic position in the education field in Australia. An important element of being President could be to detail the context of the Association in time, and I hope this is achieved in what follows.

\section{An important beginning point: Acknowledgement of Traditional Owners of Australia}

On December 4, 2018, as part of activities on what has become to be known as Blak Out Tuesday of the annual conference, AARE committed to a Statement of Reconciliation. This statement (available @ https://www.aare.edu.au/publications/docum ents/) acknowledged that "education and educational research have contributed to the enduring colonial legacy in Australian society, and ... that these institutions have not served Aboriginal and Torres Strait Islander peoples, cultures, social and legal practices, languages and lives well on many counts" (AARE 2018). ${ }^{1}$ As part

\footnotetext{
${ }^{1}$ The Statement of Reconciliation was delivered by me as President on Tuesday 4th, 2018. The

Statement was signed by the Immediate Past President Professor Martin Mills (2015-2016), myself as President (2017-2018), and Professor Debra Hayes (2019-2020) as Incoming President. Special acknowledgement is given to Professor Tracey Bunda, Dr Melitta Hogarth, Dr Kevin Lowe, Professor
} 
of making this public statement, the Association committed to a stand of inclusion and a promise to make transparent the reckoning that is still required to consider social justice education and its pursuit as more than a theoretical concept. The Statement was the result of work by a large group of members and other supporters and advisers. Members of the Aboriginal and Torres Strait Islander Research SIG led by Professor Tracey Bunda and Dr Melitta Hogarth were instrumental in both the original seeding of this initiative and in the many conversations and discussions that followed, as were so many other long-term Aboriginal and Torres Strait Islander members and colleagues, especially Dr Kevin Lowe who sat on the Executive of AARE for the two years leading up to the Statement being given. I begin this paper then by acknowledging the seen and unseen labour of Aboriginal and Torres Strait Islander researchers in the Association, and in educational research more broadly. Presenting the Statement was a highlight for me, and judging by the many emails I was sent afterward this was the case for many other members too. It was an emotionally charged moment in the Association's history-full of promise for movement towards an Association where "strong, respectful partnerships, diverse leadership, and opportunities for Aboriginal and Torres Strait Islander members' perspectives, concerns and opinions" are heard (AARE 2018). While I want to acknowledge the importance of publicly stating an Apology like that given in 2018, on the day before I delivered this Presidential Address, I resist representing the moment as a watershed. Such a representation would take the moment out of its context of the many small and large moments that served as the foundation for that one moment, the micro and macro disappointments and challenges for, and resistances by, Aboriginal and Torres Strait Islander peoples within the Association over many years. Suggesting the giving of the Statement of Reconciliation as a point that marks a time when things can never be the same (a watershed) also ignores the mountains of strategic work still required to create any real shifts in how things work within the Association. Much still needs to be done, and this will require advocacy by leaders in the Association over many years to come, and continued challenges by members to insist that this occurs. This challenging cannot be left to Aboriginal and Torres Strait Islander members alone-non-Indigenous allies must step up.

The Presidential Address reported in this paper was given on Lands of the Gadigal people of the Eora Nation. I acknowledge that the Lands were never ceded. For all who listened to my delivery of this Address, and all who are reading the Address in its written form, our lives today in this country are built on the sacrifice and dispossession of Aboriginal and Torres Strait Islander people. I acknowledge that Aboriginal and Torres Strait Islander peoples are important to our society and to education in Australia, and recognise that we will all have better lives should we choose to be enriched by the knowledges and understandings of Indigenous

Footnote 1 (continued)

Lester-Irabinna Rigney, Professor Susan Page, and Dr Graeme Gower for their tireless work and support for this initiative, as well as members of the Aboriginal and Torres Strait Island Research SIG and members of the AARE Executive for their work and support in this regard. I'd also like to acknowledge Professor Martin Mills for his part in the work. 
colleagues. Queensland University of Technology (QUT) stands on the Lands of the Yugara and Turrbal Peoples and I wish to Acknowledge their Elders, and also recognise that the Lands where QUT - my university - now stands have always been places of teaching, research and learning. Much of my research work is done on the Lands of the Yugambeh people and so I also Acknowledge their Elders, and as a way of being respectful I want to make transparent the support I receive to be able to engage in other people's Communities (Warra Davis and Woods 2019) as a researcher, educator and research partner.

\section{The heart of the matter}

Never does one open the discussion by coming right to the heart of the matter. For the heart of the matter is always somewhere else than where it is supposed to be.

(Trinh 1989, p. 1).

This paper was first presented as the Presidential Address at the 2018 AARE Annual Conference. At the time of presenting this Address I was at the end of a two-year term as President of AARE and I spent a good deal of time considering what message I wanted to mark the end of my time leading the Association. What had been the focus of my time as President? How did I want the many initiatives represented when I, or the Association and its members, looked back on this time? The two years had been busy. I had relied on many amazing members and leaders within the Association to drive the different agendas we had engaged, but here was a time to crystalise the AARE work with other dimensions of my academic work and to position AARE as a strategic association within the discipline of education one last time. Even as I finalise the writing of this paper, I find the enormity of that task a little overwhelming. What follows then is my attempt to position my leadership work in AARE within my approach to 'being' an academic - a teacher, researcher, and engaged member of the education community.

To position the discussion to be had in this paper into its surrounds, I take up Trinh T. Minh-ha's lead by starting somewhere other than where the heart of the matter might be. The discussion that follows here is not to plead or complain about being time poor-I am aware that as a Professor I have some privileges that my many precariously employed colleagues and many other early and mid-career researchers do not have access to. But having said that I do think that it is important to foreground that over many years there has been a consistent squeezing of academic time for reading, writing, thinking and analysing or critiquing. This is an issue worth commenting on. During 2020 and beyond these issues are set to become much more intense, as an already-stretched Australian tertiary sector deals with the effects of the COVID-19 pandemic and resultant losses in the international student 'market', as well as further funding cuts recently ushered in as part of the Federal Government's Jobs-ready Graduate Package (see https://www.dese.gov.au/jobready for further information). These latest reductions to university funding come on the back of more than a decade of funding decreases that have led to an over-reliance 
on selling education to international students. The latest package "sheds responsibility and tries to enforce decisions" in an attempt to "manipulate students into disciplines that politicians think are good for them" (The Australian Association of University Professors 2020, p. 1).

These very recent issues though are not the root cause of the instability of the tertiary sector, recent research conducted by an intergenerational working party of AARE members of which I was a member (see Brennan et al. 2020), that was established as a result of strong advocacy by members attending the AARE 2017 Annual General Meeting, investigated the implications of current conditions in the Australian tertiary sector on the quality of research in Australia and continuing research capacity in the field of education. The action to form the Working Party was taken by the Executive after rigorous discussions at the 2017 AGM (discussion that were mirrored at 2018 and 2019 AGMs) about the urgent need for AARE to take up a more strategic role in supporting broad participation of education academics in teaching and research, and calls from membership for the Association to do more to highlight and advocate for change to current constraints on the working conditions of education academics. Data analysed in a report by this Working Party published during 2020 were collected well before COVID-19. In this report, the working party foregrounded that certain conditions that have been in place for some years were diminishing the field of education in Australia. These include

- "Decreases in funding for the higher education sector overall;

- An over-reliance on increasing student numbers to compensate for decreasing government funds;

- University funding models that have relied on increasing funds from an increasing international student population;

- Significant costs associated with new technologies as universities move learning online and offer increasingly flexible options to students in an attempt to gain larger cohorts in a competitive student market;

- Decreases to research funding included in basic operating budgets; and

- Decreases to research funding" [opportunities].

(Brennan et al. 2020, p. 4)

So, while it is clear that COVID-19 has of course impacted on the Australian tertiary sector, this perfect storm has been brewing for some time. The Working Party (Brennan et al. 2020) reported that there was an expectation amongst Australian educational researchers that "overwork was the norm" (p. 5). It is worth noting that this expectation was not significantly different between groups of academics at different career phases-tenured professors responded in similar ways as their non-tenured early career colleagues. Nor did it seem to matter whether academics were research only or teaching only, or if they held a more traditional teaching and research position, nor which university they worked in. Indeed, the study found that almost $50 \%$ of Australian educational researchers who responded to the survey administered by the Working Party found their workloads unmanageable and many felt dissatisfaction in relation to the time they could spend on research. Adding to this, the increasing casualisation of the academic workforce in Australian universities and the 
intensification of non-research work, and the risks for educational research in Australia become evident. Educational researchers are in increasingly precarious positions as academics and while early and mid-career researchers are definitely bearing the load of many of these implications, conditions are grim for many-the cracking pace, the attendance to administrivia rather than substance, management valuing so little of what we think we do but continuing to expect more and more. Nothing to do with this situation is sustainable, and as an association, AARE and its members must prioritise these issues and take any means we can to help find solutions, and to support each other in these challenges.

Luke (2018) recently described our current situation in the preface to his collected works on literacy, schooling and social justice in these words:

The future just happened to log on early. Policy and governance, truth and lies, and the boundaries between the legal and illegal, public and private are now played out through Twitter exchanges where 140 character texts ... have become central media of news, public policy and politics... The practices, parameters and standards of human exchange and communication are in rapid transition.

(Luke 2018, p. 7)

In such a context an important focus of educational research must be how best schools and education systems can prepare people with the means to understand, access, use, and work around the codes and messages of modern communications media in ways that make visible the links to power, capital, truth and ideology. Our current context is a world of increasing inequity, increasing division, increasing shifts in the relationships between work, economy and texts, and increasing forced mobility (Luke 2018). So the work of education is being done in a context where challenges for recognition may be called louder, but are less likely to be 'heard' unless they are voiced by those who consider themselves to be the 'silenced majority'. And whether based in racist, homo/transphobic, sexist, or classist ideological principles, once such statements are put into public discourse the legacy left behind is an attack on social justice. As a result, questions asked by educational researchers interested in social justice education and schooling must include questions related to how schools, educators and community members, and children and young people might collaborate to prepare everyone to engage positive lives in these difficult and constantly changing, 'fast' economies. This occurs within social structures that have been designed to leave many behind in the interests of a few, and that seem to have small regard for the societal, environmental, cultural and health priorities that we have assumed to be important for so long.

So now to circle a little closer to where the heart of the matter might be. My first AARE conference was in Freemantle in 2001. At the time I was just in my second year of doctoral study. So I have listened to a few Presidential Addresses. Many Presidents talk about the frustration of finding time to write the Address, deciding what to talk about. How big does the talk need to be? Should it feature the findings or insights of the President's research work? For many of us, these decisions are not made alone-instead colleagues feature as advisors and sounding boards. This often unrecognised collaborative work with colleagues is crucial to sustainable futures as 
academics. The body of this paper that follows is organised by a simple structuresomething we know, something we might not know and something we should think more about. ${ }^{2}$ I begin by discussing something that all educators, researchers and policy workers and politicians know-that access to limited resources-whether economic, social or credentialed capital-has implications on the lives lived by many children in Australia and their access to education and educational futures. We all know this and yet our solutions to date have been lacking in commitment and innovative thinking. To encourage thinking beyond what we have always known, I then move to present two small extracts of data, taken from two recent research projects, asking readers to consider how listening to the voices of children and young people might open new perspectives and ideas and move educational research beyond normalised deficit understandings of communities and the logics of basic skills solutions. Before finishing the paper, I present some ideas about things that I suggest we should think more about, as educators, as allies and as Association members.

\section{Something we know}

Poverty matters. It impacts on the lives of children and young people. It intersects with race, gender, culture, language and accent, ethnicity, and sexuality, in particular spaces, cultures and locations. "Poor social and economic circumstances affect people's prospects of fulfilment throughout life" (Vinson et al. p. 6), but perhaps it is at its most stark for children and young people. Poverty is in collusion with the forces-very intentional forces in fact-that work to stratify our society, and that do so efficiently through our institutions and systems, including the institutions of schooling and education.

For many of us, we see the effects of this each time we enter a research context. For at least some of us we have experienced the effects of poverty in our own schooling and our own backgrounds. For those of us for whom the latter is the case, it is likely that access to education, especially tertiary education, was a factor in why we have been able to move to adulthoods where poverty is no longer-or at least less of a constraint. More than one Australian in every eight currently lives in poverty-that is they live below the poverty $\operatorname{line}^{3}$ (Australian Council of Social Services

\footnotetext{
${ }^{2}$ Many colleagues are implicated in what I report on here-my academic career has involved shared research, shared conversations and shared thinking of so many strong mentors and colleagues-I thank them all. The idea for how to structure this paper came from Dr Mallihai Tambya who provided me with the piece of advice that helped me to get a handle on pulling the Presidential Address together. During a supervision meeting for our shared Master's student Phil Poulton, I was expressing my concerns about what to say-Mallihai said 'tell us something we know, something we don't know and then something we need to think more about'. This sage advice ended up as the structure for the paper.

3 The definition of the poverty line taken forward by ACOSS is $50 \%$ of the middle household disposable income. Disposable income is that which is left after tax and housing costs are taken into account. This benchmark is taken up by ACOSS as it used by the OECD. However, ACOSS also report using a 60\% of middle disposable income line as this is the calculation utilised by the EU. ACOSS report that despite Australia having targets to reduce poverty, there is currently no official national poverty line defined by the Australian Government (ACOSS 2020, p. 11).
} 
(ACOSS) 2020). This figure is even worse for children, with more than 700000 thousand Australian children currently living in poverty (this equates to almost $18 \%$ of Australian children) (ACOSS 2020). Australia is a wealthy country but has high levels of poverty. To unpack these figures in 'real' life experiences I will expand drawing on some figures from ACOSS $(2020,2018)$ who inform us that Australians in the highest $1 \%$ income group have a disposable income of more than 26 times those Australians living in the lowest 5\% income group-shockingly this translates to a difference of more than $\$ 11000$ per week in disposable income. Australians in the top $1 \%$ income group consequently have more disposable income in a week than those Australians in the lowest 5\% income group have access to in a year (ACOSS 2018). The evidence about inequality in Australia tells a disparaging story for those living on low wages, those who are unemployed or underemployed and those who rely on social and government support. While those living on social support in Australia are forced to live in poverty because of the inadequacies of the support provided, we know that it is not just through unemployment that people are left behind, underemployment continues to impact on life experiences, and wage share for many sectors of the employment matrix continues to drop in alarming ways.

Further, the number of people living in poverty has been at its largest in times when the economy is at its strongest. The myth of trickle down economics does not hold up in the data. The percentage of Australians living in poverty was $11.5 \%$ in 2003 , "then rose sharply during the boom years to $14.4 \%$ in 2007", and after the Global Financial Crash (GFC), the figure fell again to 12.6\% (ACOSS 2020, p. 18). The free market works much better for some than others, and there is very little that is random about who is advantaged and who is not in countries like Australia.

It is worth considering how these economics fit with social, cultural and spatial factors in Australian society-along with our very specific policies around school choice and school funding. Social class and the lived experience of poverty or advantage, intersect with location as well as gender, ethnicity, race, culture, religion, sexuality and language, in increasingly complex demographies due in part to migration, economic policy, settlement and hardship. Space and location, and neighbourhoods and communities are also linked to, and impacted upon by, current education ideas about outcomes-about who is in and who is not and about how we represent that (Baroutsis and Woods 2018). A recent report—Dropping off the edge- (Vinson et al. 2015) maps geographic distribution of disadvantage in Australia, reporting on the 40 highest ranking Statistical Local Areas (SLA) of 'disadvantaged factor' in each of the Australian states and territories. The point of the study was not to make conclusions about the causes of poverty, but instead to uncover areas of concentrated disadvantage in Australia, and to investigate how this plays out over time.

In the areas where I am privileged to do a good deal of my research work there are a number of SLAs that rank high on the Vinson and Rawsthorne scale as very disadvantaged. But the lived experiences of those who live in these areas are not homogenous across areas. Disadvantage is increasingly concentrated, and the spatial and material conditions of this disadvantage are also evident in the geographies of communities (Massey 2005). Aerial photos of the communities where my research is conducted provide images of high-density housing and little green space. Indeed, the school yards in these communities are often the only green 
spaces to be seen. Interestingly, these school yards are often now surrounded by high fences which are locked during weekends as a way to provide security. Residential neighbourhoods are mixed with industrial use, and often surrounded by areas of lower density and larger more affluent housing areas. These neighbourhoods that surround the areas of concentrated disadvantage are often gated communities.

My point is that space is much more than a dot on the map-there are sociocultural and sociomaterial aspects to the spaces or places where educational researchers may visit to research. These are not abstractions but instead meaningful locations where people live, where they engage and are engaged in belonging-or not belonging. As social and material spaces, communities and neighbourhoods produce and reproduce the ways in which we can relate to other human and non-human elements of the spatial and social environs. And schools and education spaces are likewise involved in the production and reproduction of power, relations and politics. These education spaces mediate relational, pedagogic, and the temporal and spatial movements of those within their boundaries and also, of course, those who remain outside their boundaries.

The ways in which education systems categorise spaces in relation to outcomes and measures of disadvantage have been designed to try to represent these issues of space, location and school populations. They do this no doubt with the best of intent, to allow for some way to compare schools while taking into account that not all schools are alike. Schools, and thus children's experiences of schooling opportunities, do not necessarily have the same starting point. The process of acknowledging this in Australia involves providing each school an ICSEA rating. This Index of Community Socio-Educational Advantage (ICSEA) brings together student factors including the occupation and education level of parents of children attending the school, with school factors such as geographical location and the proportion of cohorts of children with different cultural backgrounds to provide an ICSEA score. The ICSEA score provided is then used to produce lists of 'like schools', and according to the Australian Curriculum, Assessment and Reporting Authority (ACARA) (2012, p. 1) this enables:

fair and meaningful comparisons of the performance in literacy and numeracy of students in a given school with that of similar schools serving students with statistically similar backgrounds.

These listings of 'like schools' should give some confidence that the systems of evaluation are fair and equitable. They point to the fact that the system somehow understands that not all schools are the same, so the outcomes and results of schools are not only compared to all other schools nationally, but also to a smaller set of schools that are 'like' or similar. However what happens when a school and its students' outcomes are compared with other schools just 'like' them and still the school produces results that are below its 'like' counterparts? Teachers, children and their families and communities are left to hold the blame for this under performance.

Of course what is missing in this narrative of 'likeness' or similarity is any understanding of just how unlike 'like' schools are. Any index-no matter how complex-must prioritise some characteristics or items over others, but the ICSEA score 
in all its incompleteness has come to stand as a full and complete description of a school and by connection the children who attend it, and the community that surrounds it. And when this is used to create lists of like schools, lists that compare, sort, judge and disenfranchise, then poverty really comes to matter.

Debates about education, access and equity have durable histories, seemingly resistant to change and logic. Four decades ago, Connell and colleagues produced formative research on schools, families and social division in Australia (Connell et al. 1982). At the time these researchers argued that "central government policy now tends to increase educational inequality rather than reduce it" (p. 16). So while the policy, practices and conditions of schooling may be different, it seems that so much remains the same. Public, political and even practical and academic debates tend to work in binaries and these distort and simplify the complex and gnarly problems of education. And as a result, the point of research in education must be much more than to consider teaching and learning, or seeking best methods. Knowing more about how best people can teach others and how best people can learn under the instruction of others does not-or at least should not-define educational research. Many of us researching in education put our theoretical understandings and methodological approaches to the task of pursuing educational research that considers the social, cultural, political and economic contexts, as well as the spatial and material, in which education takes place. Education is situated within the broad social, cultural, civic, political and policy endeavours of a society, a community and our research must take this into account.

If we agree that this is the case then we also agree that success and achievement in education, and how we measure this, is produced by complex social, cultural, economic and policy forces (Compton-Lilly et al. 2020). Relationships and relational ways of being are central to who we are and to how, what and why we learn (Shay 2017). As such, curriculum and pedagogy constitute just one dimension of the education outcomes equation, and yet this is often ignored. Certainly, when understandings and perspectives from outside the discipline of education are brought to the agenda of education, there is at times a certain naivety, to use the phrase of Lyn Yates (2018), about the powers of assessment, curriculum and pedagogy. There is a sense that shifting the levers of curriculum and pedagogy, or using a different test, or even more tests-will somehow have a direct and causal effect on improved outcomes, changed perceptions and new directions, new lives for students particularly those from cohorts where disadvantage plays a part in outcomes achieved. Unfortunately, it is not that simple. This is not to say that providing quality curriculum and pedagogy is not important-just that it is not the only policy or social lever that we should be adjusting. Curriculum and pedagogy matter, but cannot be the only thing left to matter if our aim is to achieve a socially just education. And of course, all those who work within schools, including educational researchers, have accountabilities to children, young people and their families and communities to provide access to a high quality and high equity education.

Current education policy is based around the economic rationalisation of old structures and technologies that were originally developed for a modernist printbased schooling system being put to work for new problems (Luke 2018). In our current policy models, there are common premises about accountability as testing; 
the positive power of standardisation as a representation of standards; marketisation of schooling in a competitive environment of school choice; central surveillance of teachers, children, and to some extent families and communities as can be seen for example in interventions that tie social support for living to educational outcomes such as school attendance; and an intensification of resourcing in some sections of the school and not others - the early years of schooling and early phonics comes to mind. There are several assumptions holding these policy moves up. These include a belief that large-scale systems' approaches and outcomes can be quantified, and that top-down systemic intervention to control and change school and teacher practice can be used as a lever to generate improved outcomes (at least those outcomes that can be measured by standardised tests).

So the logic is that the work of schools and teachers and children and young people can be steered by monitoring the smallest details of what happens in classes and schools and by monitoring student performance. What is particularly distinctive in current policy that we may not have seen other rounds of policy change is the official support being provided to a corporate political economy around pedagogy and assessment. This multimillion dollar industry in scripted pedagogies, basal levelled readers, synthetic phonics programs, comprehension cards, high definition curriculums with matching teacher and student texts and tests. It seems that the State may have shifted its support from those trained in education to those trained in business and marketing of education products.

And all of this in a context where we know that collaboration or collective action-and not individual work-will be required if the children currently in schools are to be 'successful' in future work, recreation and civic lives. We are aware that the relationships between communication and power are shifting with the rise of writing as the technology of mass literacy, and that the material conditions of communication - the very relationships between people, things, texts, technologies of communication have shifted (Brandt 2014). We are also aware that everyday life wherever it is conducted involves the entanglement of social with material, human with non-human (Fenwick et al. 2011), digital with traditional means and products of literacy and communication.

From the experiences of two decades of research in schools with my colleagues in communities, particularly those in communities where recognitive and representative justice (Fraser 2009) remain key challenges and where in most schools (but not all) access to new technologies continues to be problematic for current communication needs, I spend time in classrooms where all of these broader social factors come together with the idiosyncrasies of thirty children and several adults. It is important for those researchers who engage in classrooms to remember that the contexts where we research are the very same contexts where teachers and children try to get on with their core business, in what Luke (2018, p. 6) has called a demonstration of the durability of schooling practice and the resilience of residual tradition that goes on regardless of the change that happens around the schooling system. From the fieldwork and surveys of teachers working in the schools in these communities across numerous research projects, we know that the teaching populations in the schools that are most effected by these social and economic challenges are heavily weighted towards young staff in the first few years of their careers. Highlighting 
this as a problem is not to suggest that these early career teachers do not have much to offer the profession nor that they are not real assets to the schools in which they work and the children and families who they work with. However, such a bias in any one school or region challenges the intergenerational networks that can be developed and capitalised upon. And in times of accountability, and increased testing and surveillance-where standardisation and consistency have become the mantra-in schools where so many of the teachers have only been teaching for a few years there is no access to an institutional history, a memory of how things might be other than they are now. This situation places schools in communities of poverty at a disadvantage in terms of how they might push back on some of the mandated requirements that they know are not working in the best interests of their children. It is difficult to interrupt the logics of current policy if you have not taught in any other context. Added to this is the fact that many young or early career teachers are in precarious employment situations, engaging for many years in some cases on short-term or temporary contracts.

So to recap-poverty matters. Our current schooling contexts continue to be built on inequitable structures, that continue to be, or perhaps are increasingly, inept for dealing with the problems of today's education needs. Current education contexts are contexts of accountability, where more data are collected through more testing than ever before, and where spaces for teaching children with the purpose of moving along their learning are increasingly constrained. As educational researchers, we should know that this matters, and be concerned with finding ways to ameliorate the effects, and provide evidence for policy shifts. My claim here has been that one of the key policy and practice dilemmas for now is how school systems respond to changes in demographic, socioeconomic, cultural, social, material, spatial and technological contexts with a useful version of quality, equitable schooling. We should be interested in how and why systems continue to work in a policy context that frames the purposes of education to be the pursuit of measurable, continuous improvement of outcomes on a narrow band of literacy and numeracy skills.

\section{Something that you might not know}

In this section of the paper, I want to compare the insights from young children about schooling and two common discourses that continue to circulate as commonly accepted explanations for differentiation of outcomes. So in order to frame these insights, I will first provide a backdrop of commonly accepted policy solutions by unpacking two policy narratives that circulate-and have circulated for time on time-as logical responses to real and imagined problems with schooling and particularly with teaching children literacy (Luke and Woods 2009).

The first policy narrative provides deficit explanations of the 'failure' of children to learn literacy. Deficit discourses circulate about children who grow up in particular areas, about their families and communities, and of course they also circulate about teachers, and schools in these same areas as well. These deficit ways of understanding, work in ways that allow us to attribute blame for underperformance to individual or cohort deficiencies. Individual characteristics or 
deficits are catalogued in essentialist terms and are then available to be generalised to larger groups or to communities. This move can be seen in resilient statements in education about 'these' kids, 'these' communities and 'these' schools. The rich lives of children and young people, their skills, capacities and the intelligent ways that they go about their everyday lives become invisible. Evidence of individual deficiencies are generalised to other individuals from the same community. And yet when success or evidence to counter deficit understandings is available and cannot be ignored, it is usually attributed to only that individual, a child who does well comes to be framed as an exception to the rule.

Of course these deficit ways of understanding children and concepts such as learning and education are much more likely to affect individuals and groups who are already at the margins - white, middle class culture is normalised and all other lives are othered. Once it becomes logical to understand a child as a result of knowing others like them, or others we have known-their family, their community - it is easy to assume that any problems they may have with learning are problems located within the heads and bodies of these children, and not as a result of the education and lives we as a society offer up to them. The result of this narrative, once it seems logical to us as a way of understanding school success, is low expectations for ourselves and for education, and the ability to explain away low performance of children and young people without any requirement to consider the place of institutions, systems, schools and ourselves as educators.

The second policy narrative popular currently standardises basics and narrows the purposes of schooling (Luke and Woods 2009). It is based in assumptions that there is one best way to teach-one best curriculum or pedagogical approachthat can and should be standardised across all classrooms. This one way to teach will likely be about direct instruction of 'basics' - basic phonics, basic number facts, basic content from other disciplines-so the second narrative explains the 'problems' of schooling in the following way: "the current approaches of teaching are flawed" (p. 202), and teachers cannot be trusted to be quality teachers; it is possible for the government or systems' leaders to identify and implement a highly defined, standardised approach to pedagogy (in the case of literacy this is currently a basic or systematic phonics approach) and use this approach to monitor the behaviours of children and teachers; that once implemented progress can and should only be judged via standardised tests or assessments where children's behaviours and responses are measured, then placed onto a bell curve and labelled as A-E based on normalised versions of performance indicators, before being collected in ever increasing banks of data (Luke and Woods 2009). The logic of this narrative is that such an approach will result in improvements in test scores-especially for those "students who come from historically underperforming groups" (p. 202).

In the end both narrative one and two undermine teachers and teaching-as well as children and young people and their families and communities. Both narratives narrow the purposes of schooling to being about the transmission of basic, standardised content and frame the purpose of schooling as being about learning print-based literacy skills, and at best some basic number and science content. As Hogarth (2017) explained, policy narratives have a habit of ignoring 
the "historical, political, cultural and social factors that influence" (p. 21) school engagement and opportunity. At their very foundation, these policy narratives work to short change the children and young people who could expect the best from an education system.

The assumptions at the basis of these two policy narratives can be discredited by focussing on what children and young people can tell us about the inadequacies of such simple logics. There may never have been a time when it has been more critical to tell counter stories that resist and reposition such simple policy narratives. Now is the time to speak back to policy that does not aim to serve the best interests of all and rather serves just a select few.

The reason for detailing the following two short extracts from recent projects, and of suggesting that these might provide readers with insights into content that they may not already know, is because as adults - as teachers, policy workers and researchers-we tend not to ask children what they think very often. So in providing these short extracts I aim to give some insights from children collected as part of collaborative research projects, as a way to provide a space to consider what children might tell adults about schooling and their experiences of being educated. The second reason for including these extracts is to challenge the assumptions that underpin the deficit policy narrative, and claims from the basics narrative that teaching basic skills will solve real and perceived problems with education. In presenting these extracts, I am drawing on a number of research projects and so wish to ensure that I acknowledge that what I present is the result of shared thinking, shared research that has engaged colleagues and also those educators, children, young people and their significant adults whom I researchwith.

\section{Extract one}

The first counter narrative presented here comes from collaborative work conducted in schools in communities of poverty with Barbara Comber, Lisa Kervin and Aspa Baroutsis. ${ }^{4}$ In the Learning to Write in the Early Years (LWEYs) project we were interested in what happens when everyday literate experience is clearly about writing as well as reading, and about text production and comprehension across multiple modes-but our social institutions tasked with preparing children and young people for learning, work and civic responsibility have not necessarily caught up either with the importance of teaching writing, nor of the importance of communicating in a diverse range of modes that include but are not exclusively about print. The purpose of the project was to investigate how children learn to write, and how this learning can best be supported as a multimodal, collaborative practice. The focus of study was on the material changes to text production and how we use texts to communicate with others, as well as how we learn to do these literate practices. We started

\footnotetext{
${ }^{4}$ Learning to write: A sociomaterial analysis of text production was an Australian Research Council funded project (DP150101240). The research team included Annette Woods, Barbara Comber, Lisa Kervin and Aspa Baroutsis. I wish to acknowledge the support of the ARC, and the children, their teachers and families who were our partners in this research.
} 
with an assumption that it is not useful to separate print texts from digital texts, nor to separate our ways of researching print and digital practice. Print texts have certainly not been made redundant by digital technology, however, little is known about the implications of material changes brought about when paper and pencils sit on desks with laptops and ipads, and when children look towards whiteboards and smart boards more often than butchers' paper and chalkboards.

One small part of this much larger study has involved researchers asking children about their experiences of learning to write and it is this component of the study that I wish to discuss here. As part of data collection activities, children talked, drew and produced print and digital texts for us. When asked, children talked and drew about their experiences of learning to become writers and producers of texts in insightful ways. Interestingly, despite evidence in data collected from teachers at the schools that suggested children were not writers, and that there was minimal support for children's writing provided in their homes, listening to children provided different perspectives. Children told rich stories about writing outside of school, with detailed narratives about writing with relatives and friends, and about writing collaboratively with others as well as by themselves. They described areas set up in their homes with writing desks and resources to support text production, and told of parents and other significant adults teaching them about skills such as holding pencils and creative practices supported by people in their home contexts. One young child told us.

At home my mum and dad [help me to write]. My mum helps me write how to put the letters and full stops and if I have a problem. My dad helps me put words together and then speak them out. (Year 2 student).

Decades of research has demonstrated that assumptions about families in communities of poverty, and those that are culturally diverse not valuing schooling or having limited interest in their children's achievements is not only inaccurate but complicit in excusing systems for sustained failures in providing equitable and quality education to all (see for example Alford and Woods 2017; Baroutsis and Woods 2018; Comber 2016; Comber and Kamler 2004). The foundational work of researchers such as Heath (1983) provides evidence that there are many ways that families share literacy and language, and all are valuable to children's learning. However, deficit discourses continue to be resilient and they permeate the understandings of community that teachers and schools are able to configure. Listening to children, as we attempted to do in this project, allows us to suspend our assumptions and hear different perspectives and stories. In listening to children we gained insights into the rich communities and households that they were a part of. In our data, parents, brothers, sisters, uncles, aunties, grandparents are all mentioned as good writers, as people who support children's writing, and as reliable writing partners. The children almost all believed themselves to be good at writing and many discussed being happy to write, and about choosing to write in private or home time. Many of these same children were represented in school as reluctant writers.

The same children also had insights about teachers and teaching, and of their own learning. When asked what they would like their teacher to know about what helps them to learn to write there is evidence of children learning quickly about what it means to be a good writer in school. There are comments about spelling and neat 
handwriting, and about quiet work and being good. Children had also appropriated teacher and curriculum language and made statements about learning intentions, neat writing and finger spaces as well as using classroom language like engine tables, blue and red lines, and targets. Some children also demonstrated a keen understanding of how to behave in order to be a 'good' writer such as is demonstrated in this statement from one young child.

Just think and don't touch anything and listen to the teacher. I get a pen and I start quick. I write big and I put a full stop then put another one behind it. My teacher says fantastic. (Year 1 student).

But there are also a number of children that told us that what they would most like their teacher to know about in terms of what helps them to learn to write was time to practice and/or to think, as well as the opportunity to write about what is interesting to them.

Asking these children about their experiences of learning to write provided a different perspective on the everyday lives of these children. Their stories are counter to the deficit explanations of children and families and communities that can circulate in communities of poverty. The children in this project relayed details of rich literacy lives, about families who are interested and involved in how they learn. In fact when asked who helped them to write, the children in our study were more likely to name family, friends and classmates (47\% of instances) than they were to mention teachers and other educators (38\% of instances). This is important for educators and educational researchers to know - and a part of our responsibility as educators is to do something about reframing deficit understandings of children and their families. Listening to children may be one way to engage with these new understandings.

\section{Extract two}

Before we move beyond this section of the paper that aims to engage in content that as adults we may not know, I want to present a second extract, a small piece of data collected with young children in a prior-to-school education context. These data demonstrate that top-down, highly defined, decision making around curriculum and pedagogy does not necessarily encompass the most useful learning. It also suggests that problem or inquiry learning-play-based and discovery learning-should not be put aside in our current context of standardisation. In a study ${ }^{5}$ led by Margaret Somerville, with Iris Duhn, Paulina Rautio and Sarah Powell (see Somerville et al. 2020) we were interested in what happens when literacy and sustainability are brought together within the kindergarten curriculum (Woods and Jeffries in press). The last phase of this study involved working with

\footnotetext{
5 Naming the world: early years literacy and sustainability learning was an Australian Research Council funded project (DP160101008). The research team included Margaret Somerville, Annette Woods, Iris Duhn, Paulina Rautio and Sarah Powell as well as a team of exceptional research assistants including Sarita Galvez Michelle Jeffries, Anna Vladimirova and Susan Germaine. I wish to acknowledge the support of the ARC, and the children, their teachers and families who were our partners in this research.
} 
teachers around pedagogical choices in design-based research projects. At one research site the teacher and I were interested in impacts that resulted from the inclusion of technology, in the form of print and digital tools and resources, into outside play areas and spaces. We provided a variety of literacy materials-pens, pencils, paper, iPads and apps for children to take into their free and autonomous play during outside time. Children were free to choose to engage with these materials or not. If they did choose to engage with the materials, the ways that they interacted with the materials were not adult led, the children decided what was used and what else became part of the intra-actions that eventuated. The focus of the activities was about communicating with ourselves and with others. Interestingly, on some occasions these materials were very popular and hotly contested between children and at other times they were completely ignored.

The instance I focus on in this extract involved children taking photos using the iPads. Some children moved into activities where they used printouts of their photos to construct some maps and representations of the outdoor play areas using paper and pens as well. Some of the children asked for support to produce iBooks and received instruction in how to use a book creator app to construct digital books. Amongst all of this activity one child was taking photos of a variety of things, and showing them to a number of other children and adults. During her activity with the iPad, she found the different effects available in settings- tone, light, transparency, and she began to look at things that would look strange through different effects. She was using the iPad to refract and represent materials around her. She was also laughing a lot at the results that she was achieving, and encouraged other children to join in with her. Shortly after she began this activity, the situation became much more serious. She noticed that colours changed when she looked at objects through the iPad lens when these different effects had been added. And so began a serious cataloguing of colours. She made comparisons with light and dark versions of the colours to see if there were connections between them. She made claims about how she could change colours - a blue t-shirt of a friend for example would look purple through the iPad. She came back to me and to others regularly to report different discoveries she had made. She focussed on recording people and clothing, natural materials, other communication materials such as the pens, all the while making loud claims about her hypotheses and the scientific rules and practices that she was proving and engaging with.

For the teacher, introducing the iPads had been at least in part seen as getting the children ready for a progression to school. However, this child knew that there is much more to learning than what school might have to offer. Contrary to popular concern about children's use of smart technologies, the behaviour of this child demonstrates clearly that she understands that there is much more to an iPad than playing games. And she certainly had no notion of waiting for a lesson on colour within some predetermined curriculum content sequence before experiencing the bodily and textual as well as the material practice of learning about colour in her world.

In providing readers with these two short extracts of data, I have aimed to demonstrate the inadequacies of policy narratives based in deficit or basic skills essentialisms. By listening to children in these two projects we have evidence that such narrow policy discourses do not stand up as ways to explain education, children, 
teaching and learning, or children's lives more broadly. Education and schooling are relational, and our engagement in the spaces of schooling, the places of education, while not the answer to all problems in society, can be a part of the answer. As The New London Group (2000, p. 19) reminded us:

We cannot remake the world through schooling, but we can instantiate a vision through pedagogy that creates in microcosm, a transformed set of relationships and possibilities for social futures; a vision that is lived in schools.

\section{Something we should think more about}

During 2018, AARE was involved in a shared alliance with the Australian Teacher Educators' Association (ATEA) and the Australian Council of Deans of Education (ACDE). The project was led by Simone White with Joce Nutall, Sue Shore, Barry Downs, Martin Mills and Kathryn Bussey and myself constituting the team (see White et al. 2018). In bringing these three professional associations together to consider what might be required to strengthen a research-rich teaching profession, the project was innovative and provides a prototype for future engagements between these associations and others like them.

The Alliance Project aimed to think about what teacher education students, teachers, researchers, leaders and policy workers think is required to achieve a selfsustaining, research-rich education system in Australia. There are a number of key messages for AARE and its members that came from the research-things for us to think more about. Not least of these is that an Alliance of these three professional associations - and no doubt other associations-is possible and critical to AARE as a strategic agent in current politics. This same assumption was made in another more recent report published by AARE (see Brennan et al. 2020) in which a similar call was made for the Association to move towards building alliances with other professional associations with similar remits to support policy change in the education context. There were three key messages that emerged from the Alliance Project. These include evidence that research is highly valued by systems, teachers and teacher educators; that research literacy promotes deeper teacher engagement with the task of understanding students and student learning; and that building teacher research capacity will only result when collaborations of all involved in education become a possibility (White et al. 2020).

In several different parts of the data from the Alliance Project the concept of partnerships, and the strong relationships that need to be cultivated in order for a rich education system to become a reality is foregrounded. The call from the educators involved in the project was for integrated research partnerships that facilitate alliances between leaders, teachers, students, and their families and communities, researchers, unions and teacher accreditation colleges, and community representation from Elders and Indigenous educators in the community.

This is not a new idea. Indeed in education we have strong, longitudinal examples of such partnerships in Australia. However, the current rhetoric around improving outcomes for all students continues to hide the complex and difficult work required 
to make sustained and significant improvements in outcomes for all of our students - to achieve a high quality, high equity system (Luke et al. 2013). There is no holy grail, and there is no one package that will do the work for us. The responses to our educational problems must be just the right mix of local professionalism and informed prescription from the system. Teachers need the space to teach, students must have the space to be engaged in learning substantial curriculum content (Woods et al. 2014). Strong partnerships of engagement of all involved-educators, leaders, researchers, communities, children and young people-are important and building such partnerships requires all involved to have a focus on ensuring there is space, time and resources to foreground broad purposes for schooling, to resist narrow curriculum frames, to demand pedagogies that are high quality but also well suited to the local context. This requires that we focus on children and young people and what they need to be taught in order to learn, and to use assessment as a means to an end and not an end in and of itself. As educational researchers, we must encourage those educators, children and young people who we work with to critique and query, to problematise and puzzle — and we must also engage in these practices ourselves as a way to push back and to ask for justifications for policy and practice choices.

To sum up then, the position put forward here is that school reform for equitable education is a matter of redistributive, recognitive and representational social justice (see for example Fraser 2009; Fraser et al. 2004), and it requires collaborative partnerships between teachers, researchers and communities. Fraser's approach to conceptualising social justice reminds us that balancing a focus on the equitable redistribution of resources_-including those valued capacities, skills and understandings - while also ensuring there is recognition of the lifeworlds, experiences, cultures, languages and values and beliefs of all children and their communities are critical in this agenda. However, a notion of representation, which foregrounds the importance of diverse groups setting the grounds of what education will be for their children, is also vital. This seems to be the way to progress towards the goal of high quality, high equity education systems - to consider the possibilities of schooling in current times. However, achieving this requires that educators and researchers have the capacity to ask questions. The question to be asked of evidence-based practice is 'what' evidence. The question to be asked of national benefit is benefit for who. The questions to be asked when told that all children must learn basic skills, is whose children and whose basics. The question to be asked when told about 'these' children, is how do you know. As researchers our role is to hold the line between having high standards and the push towards standardisation, and to seek to ensure that schools are the best they can be when systems focus on those who rely on schooling the most—not those already advantaged in every other dimension of their lives. By conscientiously engaging in resistance, and working together as researchers and educators with leaders and teachers and children and young people, community members and families it may be possible to design a collectively, collaboratively constructed world that works for, and has a focus on, what is best for all children and young people. 


\section{Conclusion}

So are we there yet? The question in the title was rhetorical of course-but regardless the answer is no. The task is ongoing. Perhaps, the best we can hope for as individual or collective players in complex, networked education systems is to know where we need to head, the direction we need to take and the drive and energy that this will require. We live in an advantaged society where equity remains a key issue, an issue that continues to have implications for the present and future opportunities of many children and young people, and their educators. Current education policy disadvantages too many in the interests of too few. This is the case in the contexts in which educational researchers work as well. In 2021 this will play out in universities as they restructure their workforce, review curriculum options and digitise pedagogy - jobs will be lost and opportunities narrowed. In this paper, I have highlighted just three initiatives undertaken by AARE in recent times: the Statement of Reconciliation a small but important move towards a more inclusive association; research conducted by the Working Party which mapped the urgent need to address the state of educational research in Australia and working conditions in Australian universities; and the Alliance Project which provided a prototype for how AARE might work strategically with other Associations. All of these initiatives required partnerships and respectful collaboration. They also required action and a willingness of many members to be involved. They provide insights into how the Association might be strategic and accountable within education in a socially just world. As educational researchers - and indeed as an Association-we need to not only decide what action we will take, but whose interests will be served by our actions. To finish I return to the work of Connell and colleagues where I began this paper (Connell et al. 1982). They make the claim that the purpose of schooling-and I take this forward to education more broadly - is to equip "people with the knowledge and skills and concepts relevant to remaking a dangerous and disordered world" (p. 208). AARE is well placed and take a role in supporting its members to build capacity towards this end for our current and future dangerous and disordered worlds.

Funding Funding was provided by Australian Research Council (Grant Nos. DP150101240, DP160101008).

\section{References}

ACARA. (2012). Report on the generation of the 2012 Index of Community Socio-educational advantage (ICSEA). Author.

Australian Council of Social Sciences. (2020). Poverty in Australia 2020: Part 1 overview. Author and University of New South Wales.

Australian Council of Social Sciences. (2018). Inequality in Australia. Author and University of New South Wales.

Alford, J., \& Woods, A. (2017). Constituting 'at risk' literacy and language learners in teacher talk: Exploring the discursive element of time. Australian Journal of Language and Literacy, 40(1), $7-15$. 
Australian Association for Research in Education (AARE). (2018). Statement of Reconcilliation. AARE.

Baroutsis, A., \& Woods, A. (2018). Resisting deficit: What can children tell us about literate lives. Global Studies of Childhood, 8(4), 325-338.

Brandt, D. (2014). The rise of writing: Redefining mass literacy. Cambridge: Cambridge University Press.

Brennan, M., McPherson, A., Zipin, L., Rudolf, S., Barron, R., Rogers, B., \& Woods, A. (2020). The growing urgency of attending man, A., Zipin, L to the state of Education Research in Australian Higher Education. AARE. Available at https:/www.aare.edu.au/research-and-advocacy/recen t-research/.

Comber, B. (2016). Literacy: Place and pedagogies of possibility. Londone: Routledge.

Comber, B., \& Kamler, B. (2004). Getting out of deficit: Pedagogies of reconnection. Teaching Education, 15(3), 293-310.

Compton-Lilly, C., Dixon, K., Janks, H., \& Woods, A. (2020). Summative and formative uses of assessment and images of children: An international comparison. In C. Martin (Ed.), Handbook of research on formative assessment in pre-K through elementary classrooms. (pp. 368-390) USA: IGI Global Publishing.

Connell, RW., Ashenden, D., Kessler, S. \& Dowsett, G., (1982). Making the difference. Schools, families and social division. Allen \& Unwin.

Fraser, N. (2009). Scales of justice: Reimagining political space in a globalizing world. Columbia: Columbia University Press.

Fraser, N., Dahl, H. M., Stoltz, P., \& Willig, R. (2004). Recognition, redistribution and representation in capitalist global society: An interview with Nancy Fraser. Acta Sociologica, 47(4), 374-382.

Fenwick, T., Edwards, R., \& Sawchuk, P. (2011). Emerging approaches to educational research. Tracing the sociomaterial. London: Routledge.

Heath, S. B. (1983). Ways with words: Language, life, and work in communities and classrooms. Cambridge: Cambridge Press.

Hogarth, M. (2017). Speaking back to the deficit discourses: A theoretical and methodological approach. The Australian Educational Researcher, 44(1), 21-34.

Luke, A. (2018). Critical literacy, schooling, and social justice: The selected works of Allan Luke. London: Routledge.

Luke, A., Woods, A., \& Weir, K. (2013). Curriculum design, equity and the technical form of the curriculum. In A. Luke, A. Woods, \& K. Weir (Eds.), Curriculum, syllabus design and equity: A primer and a model (pp. 6-39). London: Routledge.

Luke, A., \& Woods, A. (2009). Policy and adolescent literacy. In L. Christenbury, R. Bomer, \& P. Smagorinsky (Eds.), Handbook of adolescent literacy research (pp. 197-219). New York: Guilford Press.

New London Group. (2000). A pedagogy of Multiliteracies: Designing social futures. In B. Cope \& M. Kalantzis (Eds.), Multiliteracies: Literacy learning and the design of social futures. London: Routledge.

Shay, M. (2017). Emerging ideas for innovation in Indigenous education: A research synthesis of Indigenous educative roles in mainstream and flexi schools. Teaching Education, 28(1), 12-26.

Somerville, M., Woods, A., Duhn, I., Rautio, P., Powell, S., McConnell-Imbriotis, A., \& Galvez, S. (2020). Big data: and the micropolitics of entanglement in the Earth's becoming. International Journal of Qualitative Studies in Education. https://doi.org/10.1080/09518398.2020.1753848.

The Australian Association of University Professors-Australia. (2020). Jon-ready graduate packagelegislation submission. Available at http://www.professoriate.org/2020/09/01/job-ready-graduatespackage-draft-legislation-submission/.

Trinh, T. M. H. (1989). Woman, native, other writing postcoloniality and feminism. Bloomington: Indiana University Press.

Vinson, T. \& Rawsthorne M., Beavis, A., \& Ericson, M. (2015). Dropping off the edge: persistent communial disadvantage in Australia. Jesuit Social Services and Catholic Social Serives Australia

Warra-Davis, J., \& Woods, A. (2019). Durithunga Boul: Socially just literacy education in one urban school. In J. Rennie \& H. Harper (Eds.), Literacy education and Indigenous Australians: Theory, Research and Practice (pp. 51-70). Philadelphia: Springer.

White, S., Nuttall, J., Down, B., Shore, S., Woods, A., Mills, M., \& Bussey, K. (2018) Strengthening a research-rich teaching profession for Australia. Australian Teacher Education Association (ATEA), Canberra; Australian Association for Research in Education (AARE), Melbourne; Australian Council of Deans of Education, (ACDE) Canberra. Available at https://www.aare.edu.au/research-andadvocacy/recent-research/ 
White, S., Down, B., Mills, M., Shore, S., \& Woods, A. (2020). Strengthening a research-rich teaching profession: An Australian study. Teaching Education. https://doi.org/10.1080/10476210.2020.17376 66.

Woods, A. \& Jeffries, M. (in press). "Monsters are coming": Recurring games to organise spaces and bodies in play. Teachers College Record.

Woods, A., Dooley, K., Luke, A., \& Exley, B. (2014). School leadership, literacy and social justice: The place of local school curriculum planning and reform. In I. Bogotch \& C. Shields (Eds.), International handbook of educational leadership and social (in)justice (pp. 509-520). New York: Springer Publishing.

Yates, L. (2018). Becoming a good education researcher. In J. Quay, J. Bleazby, S. Stolz, M. Toscano, \& R. S. Webster (Eds.), Theory and philosophy in education research (pp. 158-168). London: Routledge.

Publisher's Note Springer Nature remains neutral with regard to jurisdictional claims in published maps and institutional affiliations.

Annette Woods is a Professor in the Faculty of Creative Industries, Education and Social Justice at Queensland University of Technology. She researches and teaches in social justice, literacies, school reform, pedagogy, assessment and curriculum. She is a Chief Investigator on the Australian Research Council Centre of Excellence for the Digital Child, and with Kevin Lowe, Greg Vass and Emma Burn was recently awarded Australian Research Council funding to investigate the opportunities for embedding Indigenous curriculum content into secondary schooling curriculum. She was President of AARE in $2017-2018$ 